\title{
Production Risk Management of Organic Rice in Special Region of Yogyakarta
}

\author{
Efi Nikmatu Sholihah ${ }^{1 *}$, $\operatorname{Irham}^{2}$, Masyhuri ${ }^{3}$ \\ ${ }^{1}$ Postgraduate of Agribusiness Management, Faculty of Agriculture, Universitas Gadjah Mada \\ ${ }^{2,3}$ Faculty of Agriculture, Universitas Gadjah Mada, Jl. Flora No. 1 Bulaksumur, Yogyakarta
}

Received: 25 September 2018; Revised: 15 October 2018; Accepted: 18 October 2018

\begin{abstract}
Risk management is an important thing in organic farming to obtain optimal yields. The objective of the study are: (1) To know the factors affecting the production of organic rice in Special Region of Yogyakarta, (2) Estimate the level of production risk and the factors that affect the risks production of organic rice in Special Region of Yogyakarta, and (3) Determine the risk management of organic rice production. Data were collected from 30 respondents with proportional random sampling method. The factors affecting production and production risk of organic rice were analyzed using multiple linear regression with ordinary least square model, while the level of risk was analyzed by using coefficient of variation. The results showed by adding variables of land area and organic fertilizers can increase the production of organic rice in Special Region of Yogyakarta. Liquid fertilizer has significant effect to reduce risk of organic rice production. While the variables of land area and organic fertilizers have the potential to increase production risks. Based on the results of risk analysis it is known that the risk of organic rice production is relatively low because the value of coefficient of variation is low as well.
\end{abstract}

Keywords: coefficient of variation; multiple regression; organic; production risk

\section{How to cite:}

Sholihah, E. N., Irham, \& Masyhuri. (2018). Production Risk Management of Organic Rice in Special Region of Yogyakarta. HABITAT, 29(3), 92-98. https://doi.org/10.21776/ub.habitat.2018.029.3.11

\section{Introduction}

Organic farming becomes one of the solutions to the problems arising from the policy of green revolution in 1960 s, when chemicals were widely used to increase the production of farming. The use of excessive chemicals have an impact on environmental damage and reduced soil fertility (Mayrowani, 2012). Organic farming has been known for a long time, since humans start to know how to cultivate all the farming activities are done traditionally using organic materials (Roidah, 2013). Currently, organic farming is becoming a trend again due to the increase of public awareness of healthy lifestyle.

According to Yuliani \& Sudir (2017) organic farming has advantage, such as maintaining the balance of the soil because less of anorganic fertilizers and chemical pesticides. In addition to the advantage, organic farming also has several weaknesses. According to Roidah (2013) the weaknesses of organic agriculture

*Correspondence author

E-mail: efinikmatus@gmail.com includes the need for a fairly complex land management, at the beginning of application, it is found many problems, it takes a long time to get optimal results.

Special Region of Yogyakarta is one of the provinces that has developed organic farming for food commodities. Sleman, Bantul, and Kulon Progo have been applied organic farming. In line with non-organic farming, organic farming requires a combination of production inputs that can support production to the optimum point. Research by Novianto \& Setyowati (2009) states that the inputs which affect the organic rice production are land area, seeds, work days, organic fertilizers and water. All of these inputs need to be combined appropriately in order to obtain optimal production.

During organic rice cultivation process, farmers are often confronted with risks and can cause harm to farmers. Basically, Agriculture is an industry with high pressure, the management of agricultural enterprises will be filled with risks and uncertainty. According to Firdaus (2010) the risk that will be experienced by farmers is divided into physical risk and market risk. 
Physical risks are often caused by natural conditions and also the faults of a person. In organic farming, the physical risk of production is a risk that needs to be considered. there is a difference between the process of organic farming and conventional farming, because organic farming depends on the balance of the ecosystem. If there is a change in the ecosystem, it will have an impact on organic farming rather than conventional farming

Almost every production process was especially for agricultural production, each input used had to be managed properly in order to achive optimal production and reduce the possibility of risks (Basyarahil et al., 2016). Production risks that cause the most losses for farmers is the presence of pests and diseases that can not be predicted (Sriyadi, 2010). Pest and disease attacks can occur because of the weather changes, weeds, and less optimum maintenance. The level of production risk will affect production, farmer's income, and farmers in decision making.

Suharyanto et al., 2015 on the analysis of production and production risk which examines the risk issues in farming practices states that despite the farmers having a long experience in farming, they are not always able to achieve the expected efficiency and productivity. It is because of various risks such as the frequency of floods, drought and pest attacks. The risk of rice production in rainy season is higher than dry season. It is because of high rate of disease attack and low solar radiation intensity during rainy season.

Looking at the phenomenon, it is are interested to examine more about the risk management of organic rice production to know how to manage risk so that losses experienced by farmers can be minimized.

The objective of the study are: (1) To know the factors affecting the production of organic rice in Special Region of Yogyakarta, (2) Estimate the level of production risk and the factors that affect the risks production of organic rice in Special Region of Yogyakarta, and (3) Determine the proper risk management of organic rice production.

\section{Research Methods}

\subsection{Location and Data}

Research location was purposively determined such as in Special Region of
Yogyakarta by considering that Special Region of Yogyakarta was the province that had developed organic farming for rice commodities. Samples were taken from three districts in Special Region of Yogyakarta, which are Sleman, Bantul and Kulon Progo District. The data collected consisted of primary data and secondary data. The number of respondents taken from each district were 10 respondents using proportional sampling method. According to Etikan \& Bala (2017) proportional sampling was a technique with small restriction of minimum of sample number of unit from each category.

\subsection{Analysis Method}

This research used Just and Pope approach based on the Cobb-Douglas production function model by multiple linear regression analysis. Before being analyzed using multiple linear regression, it had to be ensured in advance that the data qualify best linear unbiased estimates (BLUE) by performing classical assumption test that consisting of normality, multicolinearity, and heteroskedasticity test. (Darmansyah et al., 2017) described the analysis of production risk obtained by estimating the production function and variance function used Cobb-Douglas production function transformed into natural logarithm (ln).

In this study, organic rice production is determined by land area, seeds, organic fertilizers, liquid fertilizer, natural pesticide, work days, farmer's age, farmer's education, and farming experience. The production function and function of organic rice variance based on the Cobb-douglas production model transformed into the following natural logarithm.

Production Function:

$\mathrm{LnY}=\beta 0+\beta 1 \ln \mathrm{X} 1+\beta 2 \ln \mathrm{X} 2+\beta 3 \ln \mathrm{X} 3+$ $\beta 4 \ln X 4+\beta 5 \ln X 5+\beta 6 \ln X 6+\beta 7 \ln X 7+\beta 8 \ln$ $X 8+\beta 9 \ln X 9+\varepsilon$

Variance Functions :

$\mathrm{Ln}^{2} \mathrm{Y}=\theta 0+\theta 1 \ln \mathrm{X} 1+\theta 2 \ln \mathrm{X} 2+\theta 3 \ln \mathrm{X} 3+$ $\theta 4 \ln \mathrm{X} 4+\theta 5 \ln \mathrm{X} 5+\theta 6 \ln \mathrm{X} 6+\theta 7 \ln \mathrm{X} 7+\theta 8 \ln$ $\mathrm{X} 8+\theta 9 \ln \mathrm{X} 9+\varepsilon$

where:

$\mathrm{Y}=$ organic rice production $(\mathrm{kg})$

$\sigma^{2} Y=$ organic rice variance

$\mathrm{X} 1=$ land area $\left(\mathrm{m}^{2}\right)$

$\mathrm{X} 2=$ seeds $(\mathrm{kg})$

$\mathrm{X} 3=$ organic fertilizers $(\mathrm{kg})$

$\mathrm{X} 4=$ liquid fertilizer (lt)

$\mathrm{X} 5$ = natural pesticide (lt) 
$\mathrm{X} 6$ = work days $(\mathrm{HOK})$

$\mathrm{X} 7$ = farmer's age (years)

$\mathrm{X} 8$ = farmer's education (years)

$\mathrm{X} 9$ = farming experience (years)

$\beta 0=$ intercept

$\beta=$ coefficient estimation parameter

$\varepsilon \quad=$ error

If there was a negative signified coeficcient variance, then the input was a production factor that reduces the risk.

\subsection{Model Test}

Hypothesis testing was done through model evaluation by looking at coefficient of determination $\left(\mathrm{R}^{2}\right)$, test of model significance $(\mathrm{F}$ test), and variable significance test (t-test). $\mathrm{R}^{2}$ was used to determine the level of fitness model estimation and to find out how much the diversity of production and productivity variance could be explained by the independent variables selected. The greater of $\mathrm{R}^{2}$ represented that the estimation model obtained was more accurate to predict the dependent variable (Gujarati, 2007).

$F$ test could be used to determine the simultaneous influence of independent variables on the dependent variable. Decision making was by looking at the value of significance or compare the value of $\mathrm{F}$ arithmetic with $\mathrm{F}$ table. Value of $\mathrm{F}$ table used in 5\% significance with degrees of freedom $\mathrm{df}_{1}=\mathrm{k}-1$ and $\mathrm{df}_{2}=\mathrm{n}-\mathrm{k}$, where $\mathrm{k}$ was the number of independent variables and $n$ was the number of respondents. If $\mathrm{F}$ arithmetic was greater than $\mathrm{F}$ table then it could be concluded that the independent variables in the model affected the dependent variable (Gujarati, 2007).

T-test was used to determine which independent variables that significantly affected the dependent variables (Gujarati, 2007). The variable affecting the dependent variable was seen from the probability of the independent variable compared to the error rate $(\alpha)$. If the probability of the independent variable was less than the error rate $(\alpha)$ then the independent variable had an effect on the dependent variable.

\subsection{Coefficient of Variation Analysis}

Measurement of the level of risk could be done by looking at the value of the coefficient of variation. The smaller the coefficient of variation the smaller the risk faced (Husain et al., 2016). The formula in calculating the coefficient of variation according to (Kurniati, 2012) is as follows:

$$
C V=\frac{5 d}{E}
$$

Where CV was the coefficient of variation of production risk, $\mathrm{Sd}$ was the standard deviation $(\mathrm{kg})$, and $\mathrm{E}$ was the average production $(\mathrm{kg})$. Before measuring the coefficient of variation, it should seek the average production of rice farmers and their standard deviations.

$$
V^{2}=\frac{\sum_{t=1}^{n}(E i-E)^{2}}{n-1}
$$

$\mathrm{V}^{2}$ was the diversity of production, $\Sigma$ was the symbol of the addition operation, Ei was the production received by the farmer $(\mathrm{kg}), \mathrm{E}$ was the average production of the farmer $(\mathrm{kg})$, and $\mathrm{n}$ was the number of respondents. While the standard deviation value $(\mathrm{Sd})$ could be obtained from the following formula:

$$
S d=\sqrt{V^{2}}
$$

\section{Results and Discussion}

In every business a combination of inputs production that is expected to produce optimal output. In addition to the combination of input there are also other factors that can affect an effort to produce optimal output. This also applies to agricultural business.

\subsection{Production Determinant}

Table 1. The factors affecting organic rice production in Special Region of Yogyakarta

\begin{tabular}{lcc}
\hline \multirow{2}{*}{ Independent Variables } & \multicolumn{2}{c}{ Coefficient } \\
\cline { 2 - 3 } & Regression \\
\hline Constanta & -0.171 & 0.913 \\
Land area $\left(\mathrm{m}^{2}\right)$ & $0.750^{* * *}$ & 0.000 \\
Seeds $(\mathrm{kg})$ & 0.027 & 0.772 \\
Organic fertilizers & & \\
(kg) & $0.289^{* *}$ & 0.012 \\
Liquid fertilizer (lt) & 0.011 & 0.835 \\
Natural pesticide (lt) & 0.027 & 0.627 \\
Work days (HOK) & -0.080 & 0.414 \\
Farmer's age (yr) & -0.063 & 0.799 \\
Farmer's education & & \\
(yr) & 0.018 & 0.921 \\
Farming experience & & \\
(yr) & 0.013 & 0.895 \\
\hline Adjusted $R^{2}$ & & 0.948 \\
F & & $60.457^{* * *}$ \\
Sig F & & 0.000 \\
\hline
\end{tabular}


In organic rice farming, there are several factors that can affect the production such as land area, seeds, organic fertilizers, liquid fertilizer, natural pesticide, work days, farmer's age, farmer's education, and farming experience. The result of analysis of organic rice production function can be seen in Table 1 .

Based on regression analysis results, the adjusted $\mathrm{R}^{2}$ are 0.948 , it means that $94.8 \%$ variation of organic rice production can be explained by independent variable. While based on the value of significance $F$ that independent variables on the regression model simultaneous have a significant effect on organic rice production at $99 \%$ confidence level. The effect of each independent variable on the dependent variable can be seen from the t-test or partial test.

\section{a. Land Area}

Land area has a significant effect on the production of organic rice in Special Region of Yogyakarta. The value of land area coefficient of 0.750 that means each additional land area of $1 \%$ will increases the production of organic rice by $0.774 \%$. This is supported by research Rama et al. (2016), addition of land areas on wet paddy fields can increase rice production.

b. seeds

The number of seeds used did not have a significant effect on the production of organic rice in Special Region of Yogyakarta. That was contrast to the findings of Novianto \& Setyowati (2009) which stated that the number of seeds used had a significant positive effect on production.

\section{c. Organic fertilizers}

Organic fertilizer used by farmers in cultivating organic rice had a significant effect on organic rice production in Special Region of Yogyakarta. The value of organic fertilizer coefficient of 0.289 that means each addition of organic fertilizer by $1 \%$ would increase the production of organic rice by $0.289 \%$. The application of organic fertilizers could improve soil fertility so the productivity of the soil increased and would impact on increasing production of organic rice.

\section{d. Liquid fertilizer}

Liquid fertilizer applied did not have a significant effect on the production of organic rice in Special Region of Yogyakarta. This condition showed there was no significant difference with the application of liquid fertilizer.
This was because the land was quite nutritious with the application of organic fertilizer.

\section{e. Natural pesticide}

In this study the applied natural pesticide had no significant effect on the production of organic rice in Special Region of Yogyakarta. This was because organic cultivated rice tended to be more resistant to pests and diseases. This was supported by research Yuliani \& Sudir (2017) that organic farming was able to suppress the proportion of insect pests and maintain the proportions of natural enemies.

f. Work days

Work days devoted to caring for cultivation plants from seeding to harvest had no significant effect on the organic rice production in Special Region of Yogyakarta. This condition indicated there was nothing difference between farmers who spend more time taking care of their cultivated rice with farmers who did not spent much time looking after their cultivated rice.

\section{g. Farmer's age}

Farmer's age did not have a significant effect on the organic rice production in Special Region of Yogyakarta. This condition showed that there was nothing difference between young farmers and old farmers in producing organic rice. This was supported by research from Rama et al. (2016) which explained that farmer's age had no effect on rice production in wetlands.

h. Farmer's education

In this study farmer's education did not have a significant effect on the organic rice production in Special Region of Yogyakarta. This was supported by research Rama et al. (2016) which explained that the level of farmer's education has no effect on rice production in wetlands or dryland.

i. Farming experience

Farming experience did not have a significant effect on organic rice production in Special Region of Yogyakarta. This condition indicated there was no significant difference between farmers who had longer organic farming experience with farmers with minimal experience.

\subsection{Production Risk}

Every input used had to be managed properly in order to achieve optimal production and reduce the possibility of adverse effects of of 
risks. Result of analysis of production function of organic rice can be seen in Table 2.

Table 2. Factors that affecting the risk of organic rice production in Special Region of Yogyakarta

\begin{tabular}{lcc}
\hline & \multicolumn{2}{c}{ Coefficient } \\
Independent Variables & \multicolumn{2}{c}{ Regression } \\
\cline { 2 - 3 } & $\begin{array}{c}\text { Coefficie } \\
\text { nt }\end{array}$ & Sig. \\
\hline Constanta & -0.036 & 0.896 \\
Land area $\left(\mathrm{m}^{2}\right)$ & 0.014 & 0.583 \\
Seeds $(\mathrm{kg})$ & -0.024 & 0.159 \\
Organic fertilizers & & \\
(kg) & 0.019 & 0.318 \\
Liquid fertilizer (lt) & $-0.003^{* *}$ & 0.067 \\
Natural pesticide (lt) & -7.900 & 0.999 \\
Work days (HOK) & -0.001 & 0.968 \\
Farmer's age (yr) & -0.019 & 0.667 \\
Farmer's education & & \\
(yr) & -0.025 & 0.451 \\
Farming experience & & \\
(yr) & -0.008 & 0.648 \\
\hline Adjusted $R^{2}$ & & 0.182 \\
F & & $20.756^{* * *}$ \\
Sig F & & 0.000 \\
\hline
\end{tabular}

The results showed that the estimation of the model of production variance function gave the coefficient of determination $\left(\mathrm{R}^{2}\right)$ value of 0.182 which showed that $18.2 \%$ diversity of production variance could be explained by the variation of independent variables in the model and the remaining $82.8 \%$ other factors from outside the model such as pest and disease attacks, natural conditions, sasonal changes, and other factors.

Based on Table 2., The coefficient of determination $\left(\mathrm{R}^{2}\right)$ value are 0.182 which showed that $18.2 \%$ diversity of production variance could be explained by the variation of independent variables in the model and the remaining $82.8 \%$ other factors from outside the model such as seasonal changes, farmer management, and other factors.

Variable of Seed $(-0.024)$, liquid fertilizer $(-0.003)$, natural pesticide $(-7.900)$, work days $(-0.001)$, farmer's age $(-0.019)$, farmer's education (-0.025), and farming experience $(-0.008)$, became a factor causing decreased production risk. It is means that addition of seeds, liquid fertilizer, natural pestice, work days, farmer's age, farmer's education and farming experience by $1 \%$ can reduce the production risk according to the value of the parameter coefficients.

While factors such as land area (0.014) and organic fertilizer (0.019) became the factors causing the increased production risk. However, based on the $t$ test conducted on all independent factors, it showed that only land area had a significant effect on production risk ( $p$-value> $5 \%)$.

\subsection{Coefficient of variation analysis}

The size of farming risk is required to be measured so the severity of risk can be discovered. The level of farming risk can be seen from variance, standard deviation, and coefficient of variation. Variance can be measured by summing the difference of the square of the return and the expectation of return multiplied by the probability of each occurrence. While the standard deviation can be measured from the square root of the variance value, and the coefficient of variation can be measured from the standard deviation ratio with the expected return of an asset. The level of the risk of organic rice production can be seen in Table 3 .

Table 3. Level of the risk of organic rice production

\begin{tabular}{lr}
\hline \multicolumn{1}{c}{ Period } & \multicolumn{1}{c}{$\begin{array}{c}\text { Produktivity } \\
(\mathrm{Kg} / \mathrm{Ha})\end{array}$} \\
\hline MT1 $(\mathrm{Kg} / \mathrm{Ha})$ & 8145.754 \\
MT2 $(\mathrm{Kg} / \mathrm{Ha})$ & 7060.913 \\
MT3 $(\mathrm{Kg} / \mathrm{Ha})$ & 8340.397 \\
Expected return $(\mathrm{E})$ & 7849.021 \\
Variance $\left(\mathrm{V}^{2}\right)$ & 32779.840 \\
Standart deviation $(\mathrm{Sd})$ & 181.052 \\
Coefficient of variation & 0.023 \\
$(\mathrm{CV})$ & \\
\hline
\end{tabular}

a. Standard deviation (Sd)

Standard deviation value was directly proportional to the variance. The greater of variance, the greater the standard deviation. The greater the standard deviation value, the greater the risk that must be borne by the farmers, otherwise the smaller the standard deviation value the smaller the risk borne by the farmers.

\section{b. Coefficient of variation $(\mathrm{CV})$}

The coefficient of variation was the comparison between the standard deviation value and the expected result value. The value of coefficient of variation obtained from calculation 
result was 0.023 which meant for every $1 \mathrm{~kg}$ obtained by farmer, production risk equal to $0.023 \mathrm{~kg}$.

\section{c. Expected return (E)}

The expected return was calculated from the amount of productivity obtained by organic rice farmers for one year. The value represented the net production expected by farmers in every production process in the future. The average value of the observed production was 7849.021 $\mathrm{kg}$ which indicated that the value was the result expected by the farmer in the next period.

\section{d. Varians $\left(\mathrm{V}^{2}\right)$}

The greater the value of the variance produced, the greater the irregularities occured, so the risks facing the farmers were greater. Similarly on the contrary, the smaller the value of variance the smaller the risk faced by farmers. In this study the value of variance was 32779.840 .

\subsection{Risk Management}

Based on the result of factor analysis that affected the risk of production of organic rice (Table 2.) it was known that the factors of production partially had no real effect to the risk of organic rice production. However, there were some production inputs that increased and decreased the risks so that proper management was required.

\section{a. Risk reduction factors}

Based on the results of analysis of seven variables in the model, it had the potential to reduce the risk of seeds, liquid fertilizer, natural pesticide, working days, farmer's age, farmer's education, and farming experience. The addition of the number of seeds used would help reduce the potential risks of course seeds variables could reduce the level of risk if the seeds used came from varieties that were resistant to pest and disease attacks. In the cultivation of organic rice, certified seeds was not yet available so that farmers could use local seeds from the previous season's harvest which of course was also cultivated organically. In addition, the selection of seed varieties could also be adapted to weather and climate so that the water needed could be met optimally.

Liquid fertilizer is also a variable that can reduce the potential risks. The addition of the application of liquid fertilizer will help meet the nutritional needs of the plant other than solid organic fertilizers. If a solid organic fertilizers needs to decompose first on the ground, liquid fertilizer is able to absorb the plant quickly. However the addition of liquid fertilizer should be managed. The addition of liquid fertilizer should not be excessive because it makes the plant too moist and cause rottenness.

Variables of natural pesticide were also one of the variables that was able decrease the potential risk. The application of natural pesticide should be done not only when pests occur, but every season is planted even if there is no pest attack, thus it is to prevent the pest attacks that exceed the threshold. In addition to these three factors, another influential factor to lower the risk is labor. In order for rice to produce optimal production, a proper handling and care are needed. There should be more time allocated to treat rice for example to weed routinely so that rice does not fight nutrients with weeds.

Variables of farmer's age, farmer's education and farming experience are also a risk reducing variable, so it needs to do counseling and training related to organic rice cultivation so that knowledge of farmers about organic rice cultivation increased.

\section{b. Risk increasing factors}

In addition to the factors causing the decline in the potential risks, there are factors that cause increased production risks are variable land area and organic fertilizers. The more land that is managed for cultivation will certainly increase the difficulty for farmers. Therefore, sometimes farmers need labor from outside the family. Increased risk due to additional land can be overcome by the addition of manpower so that the land can still be managed properly.

Another variable that causes increased risk is organic fertilizers. Application of organic fertilizers can indeed help improve soil fertility. However, excessive use of fertilizer will cause the soil to become acidic and difficult to cultivate. In addition, the use of excessive fertilizer will make more weeds to grow so that must be cleaned regularly. In order to overcome the need for fertilization should be done as necessary and should not be excessive.

\section{Conclusion}

The factors affecting the production of organic rice are the land area and organic fertilizers, while the factors that influence in decreasing the risk of organic rice production is liquid fertilizer. The risk of organic rice 
production is low because the coefficient value of the variation is small, the value of the smaller variation coefficient indicates the variability of the average value on the distribution is low. This illustrates the risks faced in obtaining such low production.

It is necessary to increase the land area and organic fertilizers to increase production, and the addition of application of liquid fertilizer due to the addition of liquid fertilizer that has a significant affect on the decreased production risk. Liquid fertilizer will add nutrients to the plant apart from the application of organic fertilizers. Farmers should continue to use organic farming because the risk of producing organic rice is very low.

\section{References}

Basyarahil, A., Irham, \& Waluyati, L. R. (2016). How to Mitigate The Production Risks on Coastal Red Chilli Farming in Kulon Progo Regency. Ilmu Pertanian (Agricultural Science), 1(1), 37-46.

Darmansyah, E., Muani, A., \& Radian. (2017). Analisis Risiko Produksi Usahatani Jeruk Siam Pontianak di Kabupaten Sambas. Jurnal Social Economic of Agriculture, 6(1), 13-23.

Etikan, I., \& Bala, K. (2017). Sampling and Sampling Methods. Biometrics \& Biostatistics International Journal, 5(6), 5-7.

Firdaus, M. (2010). Manajemen Agribisnis. Jakarta: Bumi Aksara.

Gujarati, D. N. (2007). Dasar-dasar Ekonometrika (Jilid I). Jakarta: Erlangga.

Husain, T. K., Mulyo, J. H., \& Jamhari. (2016). Analsis Perbandingan Keuntungan dan Risiko Usaha Perikanan Rakyat Sistem Monokultur dan Polikultur di Kabupaten Pangkep. Agro Ekonomi, 27(2), 136-149.

Kurniati, D. (2012). Analisis Risiko Produksi dan Faktor-faktor yang Mempengaruhinya Pada Usahatani Jagung di Kecamatan Mempawah Hulu Kabupaten Landak. Jurnal Sosial Ekonomi Pertanian, 1(3), 60-68.

Mayrowani, H. (2012). Pengembangan Pertanian Organik di Indonesia. Jurnal Forum Penelitian Agro Ekonomi, 30(2), 91-108.
Novianto, F. W., \& Setyowati, E. (2009). Analisis Produksi Padi Organik di Kabupaten Sragen. Jurnal Ekonomi Pembangunan, 10(2), 267-288.

Rama, R., Nurliza, \& Dolorosa, E. (2016). Analisis Risiko Produksi Usahatani Padi Lahan Basah dan Lahan Kering di Kabupaten Melawi. Jurnal Social Economic of Agriculture, 5(1), 73-88.

Roidah, I. S. (2013). Manfaat Penggunaan Pupuk Organik untuk Kesuburan Tanah. Jurnal Universitas Tulungagung BONOROWO, 1(1), 30-42.

Sriyadi. (2010). Risiko Produksi dan Keefisienan Relatif Usahatani Bawang Putih di Kabupaten Karanganyar. Jurnal Pembangunan Pedesaan, 10(2), 69-76.

Suharyanto, Rinaldy, J., \& Ngurah Arya, N. (2015). Analisis Risiko Produksi Usahatani Padi Sawah. AGRARIS: Journal of Agribusiness and Rural Development Research, 1(2), 70-77.

Yuliani, D., \& Sudir. (2017). Keragaan Hama, Penyakit, dan Musuh Alami Pada Budidaya Padi Organik. Jurnal Agro, IV(1), 50-67. 